\title{
Adenoviral vectors encoding tumor necrosis factor- $\alpha$ and FasL induce apoptosis of normal and tumoral anterior pituitary cells
}

\author{
M Candolfi ${ }^{1,2}$, G Jaita ${ }^{1}$, D Pisera ${ }^{1}$, L Ferrari ${ }^{1}$, C Barcia ${ }^{2}$, C Liu ${ }^{2}$,

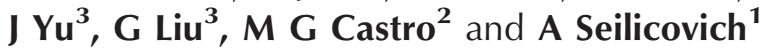 \\ ${ }^{1}$ Centro de Investigaciones en Reproducción, Facultad de Medicina, Universidad de Buenos Aires, Paraguay 2155, Buenos Aires (C1121ABG), Argentina \\ ${ }^{2}$ Gene Therapeutics Research Institute, Cedars-Sinai Medical Center and Department of Medicine and Molecular and Medical Pharmacology, David Geffen \\ School of Medicine, UCLA, 8700 Beverly Blvd, Davis Building, Suite 5090, Los Angeles, California 90048, USA \\ ${ }^{3}$ Maxine Dunitz Neurosurgical Institute, Cedars-Sinai Medical Center, Los Angeles, California 90048, USA \\ (Requests for offprints should be addressed to M G Castro; Email: Maria.Castro@cshs.org)
}

\begin{abstract}
Our previous work showed that tumor necrosis factor (TNF) $-\alpha$ and FasL induce apoptosis of anterior pituitary cells. To further analyze the effect of these proapoptotic factors, we infected primary cultures from rat anterior pituitary, GH3 and AtT20 cells with first-generation adenoviral vectors encoding TNF- $\alpha$, FasL or, as a control, $\beta$-galactosidase ( $\beta-\mathrm{Gal})$, under the control of the human cytomegalovirus promoter. Successful expression of the encoded transgenes was determined by immunocytochemistry. Although we observed basal expression of TNF- $\alpha$ and FasL in control cultures of anterior pituitary cells, fluorescence-activated cell sorting (FACS) cell cycle analysis showed that the overexpression of TNF- $\alpha$ or FasL increases the percentage of hypodiploid lactotropes and somatotropes. Nuclear morphology and TUNEL staining revealed that the cells undergo an apoptotic death process. We detected strong immunoreactivity for TNFR1 and
\end{abstract}

Fas in the somatolactotrope cell line GH3. TNF- $\alpha$, but not FasL, was expressed in control cultures of GH3 cells. The infection of GH3 cells with adenovirus encoding TNF- $\alpha$ or FasL increased the percentages of hypodiploid and TUNEL-positive cells. TNF- $\alpha$ or FasL immunoreactivity was not observed in the corticotrope cell line AtT20. However, adenovirus encoding TNF- $\alpha$ or FasL efficiently transduced these cells and increased the percentages of hypodiploid and TUNEL-positive cells. The expression of $\beta-G a l$ was detected in all these cultures but did not affect cell viability. In conclusion, these results suggest that death signaling cascades triggered by TNF receptor 1 (TNFR1) and Fas are present in both normal and tumoral pituitary cells. Therefore, overexpression of proapoptotic factors could be a useful tool in the therapy of pituitary adenomas.

Journal of Endocrinology (2006) 189, 681-690

\section{Introduction}

Although most pituitary tumors are benign, aggressive local growth can occur. Altered pituitary hormone release often leads to serious clinical disorders, such as acromegaly, Cushing's disease and sexual dysfunction (Melmed 2003). Pituitary tumors arise from any of the highly differentiated cell types present in this gland. The genesis of pituitary adenomas is believed to involve cell transformation due to genetic mutations, followed by central, peripheral and local signals that induce cell proliferation, thus stimulating tumor progression (Asa \& Ezzat 2002). Supporting the theory of intrinsic pituitary defects is the monoclonal nature of pituitary adenomas (Alexander et al. 1990, Herman et al. 1990). Considering that the regulation of tissue homeostasis results from the balance between cell proliferation and death, and that the cells bearing genetic alterations are physiologically elimi- nated by apoptosis, defects in cell death processes play an important role in tumor genesis and progression (Norbury \& Zhivotovsky 2004). Also, evasion of cell death can lead to the selection of immortal transformed cells (Eischen et al. 2001).

Death receptors, such as Fas (receptor for FasL), tumor necrosis factor receptor 1 (TNFR1; one of the receptors for TNF) and DR5 (receptor for TNF-related apoptosisinducing ligand (TRAIL)) are type-I membrane proteins that have a conserved domain called the death domain. Upon binding to the specific ligand, death receptors form trimers (Ashkenazi \& Dixit 1998, Evan \& Littlewood 1998). The apopotic signal transduction cascade that is induced by death receptor activation has been well characterized. Ligation of Fas by FasL or TNFR1 by TNF- $\alpha$ results in formation of a death-inducing signalling complex (DISC), which initiates a cascade of events that, through activation of caspases 8 and 10, leads to apoptosis 
(Scaffidi et al. 1999, Chen \& Goeddel 2002). The initiator caspases can either directly activate executioner caspase 3 or cleave $\mathrm{Bid}$, a proapoptotic member of the Bcl-2 family. The truncated Bid translocates to the mitochondria stimulating cytochrome $c$ release (Gonzalvez et al. 2005). Cytochrome $c$, together with Apaf-1 activates caspase 9, which in turn activates caspase 3 (Cecconi 1999). Then, caspase 3 and other downstream caspases cleave subtrates involved in cell disassembling (Degterev et al. 2003).

The anterior pituitary gland undergoes a process of cell renewal during the estrous cycle in the female rat (Hashi et al. 1995, Yin \& Arita 2002). We have previously reported that TNFR1 and Fas activation induce apoptosis of anterior pituitary cells from female rats (Candolfi et al. 2002, 2004, 2005, Jaita et al. 2005b) suggesting that TNF- $\alpha$ and FasL are involved in the maintenance of tissue homeostasis in the anterior pituitary gland and could have potential benefits for the treatment of pituitary diseases. Although major advances have been made in the therapy of pituitary tumors, only partial success has been possible and novel therapies are needed. Thus, we explored the effect of first-generation recombinant adenoviral vectors (RAd) encoding TNF- $\alpha$ and FasL in normal and tumoral anterior pituitary cells. Our previous results have demonstrated the persistent high efficiency of transgene expression of adenoviral vectors encoding $\beta$-galactosidase or herpes simplex virus (HSV) Type 1 thymidine kinase in the anterior pituitary gland (Castro et al. 1997, Southgate et al. 2000b, 2001, Smith-Arica et al. 2001). In the present work, we tested the ability of adenoviral vectors encoding TNF- $\alpha$ (RAd-hCMV-TNF- $\alpha$ ) or FasL (RAd-hCMVFasL) to infect and express these proapoptotic transgenes within anterior pituitary cells from two different rat strains and also in the pituitary cell lines GH3 and AtT20. We investigated the proapoptotic effect of the vectors expressing TNF- $\alpha$ and FasL by fluorescence-activated cell sorting (FACS) analysis and the TUNEL method in both normal and tumoral pituitary cells. We found that adenoviral vectors encoding these proapoptotic genes are successfully expressed in pituitary cells, triggering the apoptotic cascade. Our results suggest that death receptors could possibly be considered as a target for the treatment of pituitary adenomas.

\section{Material and Methods}

\section{Drugs}

All culture media and supplements were obtained from Invitrogen, except fetal bovine serum (Biomeda, Foster City, CA, USA) and the materials indicated below. All TUNEL reagents were purchased from Roche. The primary antibodies against anterior pituitary hormones were purchased from Dr A Parlow at the National Hormone and Pituitary Program (Torrance, CA, USA). Secondary antibodies were obtained from DAKO
(Glostrup, Denmark) and Chemicon International (Temecula, CA, USA). Avidin and biotin blocking solutions, fluorescein-avidin, diaminobenzidene (DAB), Vectastain ABC Elite kit and Vectashield were from Vector Laboratories Inc (Burlingame, CA, USA).

\section{Adenoviral vectors}

The RAd vectors used are based on adenovirus type 5 (Ad5), in which the left end of E1 and a portion of the E3 regions are deleted $(\mathrm{E} 1-/ \mathrm{E} 3-)$, and a cassette containing a recombinant exogenous gene and promoter is inserted in place of the E1 deletion. Three different vectors were used: RAd-hCMV-TNF- $\alpha$ (Ehtesham et al. 2002), RAd-hCMV-FasL (Larregina et al. 1998, Morelli et al. 1999, Maleniak et al. 2001) and RAd-hCMV- $\beta-G a l$ (Castro et al. 1997). The RAds were grown and purified as previously described (Lowenstein et al. 1996, Southgate et al. 2000a).

\section{Animals}

Adult female Wistar and Sprague-Dawley rats were kept in controlled conditions of light (12 h light: $12 \mathrm{~h}$ darkness cycles) and temperature $\left(20-25^{\circ} \mathrm{C}\right)$. Standard laboratory chow and water were freely available and rats were kept in accordance with the NIH Guide for the Care and Use of Laboratory Animals. Anterior pituitary glands were removed within minutes after rats were killed by breathing $\mathrm{CO}_{2}$, followed by physical induction of pneumothorax.

\section{Cell culture}

A pool of anterior pituitary cells from five rats was used for each primary cell culture. Anterior pituitary glands were washed several times with Dulbecco's modified Eagle's medium (DMEM) and cut into small fragments. Sliced fragments were dispersed enzymatically by successive incubations in DMEM supplemented with $3 \mathrm{mg} / \mathrm{ml}$ BSA, containing $2.5 \mathrm{mg} / \mathrm{ml}$ trypsin (Type I from bovine pancreas), $1 \mathrm{mg} / \mathrm{ml}$ DNase (deoxyribonuclease II, Type V from bovine spleen) and $1 \mathrm{mg} / \mathrm{ml}$ trypsin inhibitor (Type II-S from soybean), and finally dispersed by extrusion through a Pasteur pipette in Krebs buffer without $\mathrm{Ca}^{2+}$ and $\mathrm{Mg}^{2+}$. Dispersed cells were washed twice and resuspended in DMEM supplemented with $10 \mu \mathrm{l} / \mathrm{ml}$ MEM aminoacids, $2 \mathrm{mM}$ glutamine, $5 \cdot 6 \mu \mathrm{g} / \mathrm{ml}$ amphotericin B and $25 \mu \mathrm{g} / \mathrm{ml}$ gentamicin (DMEM-S or MEM-D-valineS). Cell viability, as assessed by trypan blue exclusion, was over 90\%. Cells were cultured in DMEM-S with $10 \%$ heat-inactivated fetal bovine serum for $1-2$ days $\left(37^{\circ} \mathrm{C}\right.$, $5 \% \mathrm{CO}_{2}$ in air) before $\mathrm{RAd}$ virus infection.

GH3 and AtT20 cells (Castro et al. 1997) were cultured in MEM containing $10 \mu \mathrm{l} / \mathrm{ml}$ non-essential aminoacids, 
$10 \mu \mathrm{l} / \mathrm{ml}$ L-glutamine, $10 \mu \mathrm{l} / \mathrm{ml}$ penicillin/streptomycin and $10 \%$ fetal calf serum $24 \mathrm{~h}$ prior to RAd virus infection.

Anterior pituitary cells, as well as GH3 and AtT20 cells were seeded onto coverslides in 24-well tissue culture plates $\left(10 \times 10^{4}\right.$ cells $/ 0.5 \mathrm{ml}$ per well $)$ for the TUNEL method or immunocytochemistry, and onto 24-well tissue culture plates $\left(25 \times 10^{4}\right.$ cells $/ 0.5 \mathrm{ml}$ per well $)$ for flow cytometry (FACS). Then, cells were infected for $48 \mathrm{~h}$ with different doses of viral vectors expressed as infectious units/cell (IU/cell) of adenoviral vectors expressing human TNF- $\alpha$ (RAd-hCMV-TNF), murine FasL (RAd-hCMV-FasL) or the Escherichia coli enzyme, $\beta$-galactosidase (RAd-hCMV- $\beta-G a l$ ) under the control of the human cytomegalovirus (hCMV) promoter (Southgate et al. 2000b, Windeatt et al. 2000). After this period, cells were fixed for immunocytochemistry and TUNEL or flow cytometric analysis.

\section{Immunocytochemistry of TNFR1, TNF- $\alpha, F a s, F a s L$ and $\beta$-Gal}

We identified the presence of TNFR1, TNF- $\alpha$, Fas, FasL and $\beta-G a l$ in anterior pituitary cells by immunocytochemistry using rabbit anti-TNFR1 antibody (1:50; Stressgen, CA, USA), mouse anti-Fas antibody (1:50; Stressgen), rabbit anti-TNF- $\alpha$ (1:50; Endogen, IL, USA), rabbit anti-FasL antibody (1:25; Santa Cruz Biotech, CA, USA), and rabbit anti- $\beta-G a l$ (1:1000, developed in our laboratory (Southgate et al. 2000b)) respectively. Briefly, after the culture period, cells were fixed with $4 \%$ formaldehyde in PBS for 30 min followed by an incubation with $10 \%$ normal donkey serum in PBS with $0.2 \%$ Triton $\mathrm{X}-100$. After incubation with $0 \cdot 3 \% \mathrm{H}_{2} \mathrm{O}_{2}$ to inactivate endogenous peroxidase, or with avidin and biotin blocking solutions, cells were incubated overnight with primary antibodies in PBS containing 1\% donkey serum. To detect $\beta-G a l$, cells were incubated with the primary antibody for $1 \mathrm{~h}$. After rinsing, slides were incubated for $1 \mathrm{~h}$ with the corresponding biotinylated donkey anti-mouse or antirabbit $\operatorname{IgG}$ at a 1:200 dilution in the same buffer. Biotinylated antibodies were labeled with Vectastain ABC Elite kit, followed by staining with $\mathrm{DAB}$ and glucose oxidase (Sigma), and dehydration through graded ethanol solutions or with $2 \mu \mathrm{g} / \mathrm{ml}$ fluorescein-conjugated avidin in $10 \mathrm{mM}$ HEPES buffer, $\mathrm{pH} 7 \cdot 5$. Finally, slides were mounted with Vectashield, a mounting medium for fluorescence, containing DAPI (4',6-diamino-2phenylindole dihydrochloride; Sigma) for DNA staining; slides were visualized in a fluorescence microscope (Axiophot, Carl Zeiss, Jena, Germany) or a confocal microscope (Leica, Germany) or mounted with DPXmounting medium (Fluka, Switzerland) for light microscopy. Control slides were incubated with the corresponding $\operatorname{IgG}$ subtype instead of primary antibody.

\section{Microscopic determination of DNA fragmentation by the} TUNEL method

The TUNEL method was performed as previously described (Candolfi et al. 2002). Briefly, after the culture period, cells were fixed with $4 \%$ formaldehyde in PBS for $30 \mathrm{~min}$ and permeabilized by microwave irradiation. DNA strand breaks were labeled with digoxigenin-dUTP using terminal deoxynucleotidyl transferase $(0 \cdot 18 \mathrm{U} / \mu \mathrm{l})$ according to the manufacturer's protocol. The incorporation of nucleotides into the $3^{\prime}-\mathrm{OH}$ end of damaged DNA was detected with an anti-digoxigenin-fluorescein antibody.

\section{Flow cytometric analysis (FACS)}

Cultured cells were harvested with trypsin-EDTA, fixed with $75 \%$ ice-cold ethanol and permeabilized with $0 \cdot 1 \%$ Triton-X100. Afterwards, cells were incubated in the presence of propidium iodide $(50 \mu \mathrm{g} / \mathrm{ml})$ and RNAse $(10 \mu \mathrm{g} / \mathrm{ml})$ in PBS with $0 \cdot 1 \%$ sodium azide. In the case of normal anterior pituitary cells, prior to incubation with propidium iodide, cells were incubated for $1 \mathrm{~h}$ with anti-rat prolactin (NHPP-IC, 1:1000) or anti-rat growth hormone (NHPP-IC, 1:2000) guinea pig primary antibodies in PBS containing 1\% donkey serum and $0 \cdot 1 \%$ sodium azide, followed by an incubation for $1 \mathrm{~h}$ with fluorescein-conjugated donkey anti-guinea pig secondary antibody. The percentage of hypodiploid cells (Sub-G1) was determined using a FACScan (Becton Dickinson, Franklin Lakes, NJ, USA).

\section{Statistical analysis}

Percentages of hypodiploid (Sub-G1) cells, as analyzed by FACS, were expressed as means \pm S.E. and evaluated by ANOVA followed by Dunnet's multiple comparison test. The number of apoptotic cells, as identified by the TUNEL method, was analyzed in duplicate slides from at least two independent experiments. Results were expressed as the percentage of apoptotic cells $\pm 95 \%$ confidence limits (CL) of the total number of cells counted in each specific condition. Confidence intervals for proportions were analyzed by the $\chi^{2}$ test. $P<0.05$ was used as the cut-off point for significance. All experiments were performed at least twice.

\section{Results}

TNF- $\alpha$ and FasL transgene expression in normal anterior pituitary cells

Our previous work showed that both TNF- $\alpha$ and FasL induce apoptosis of anterior pituitary cells (Candolfi et al. 2002, 2004, 2005, Jaita et al. 2005b). Now, we overexpressed TNF- $\alpha$ and FasL in primary cultures of anterior 

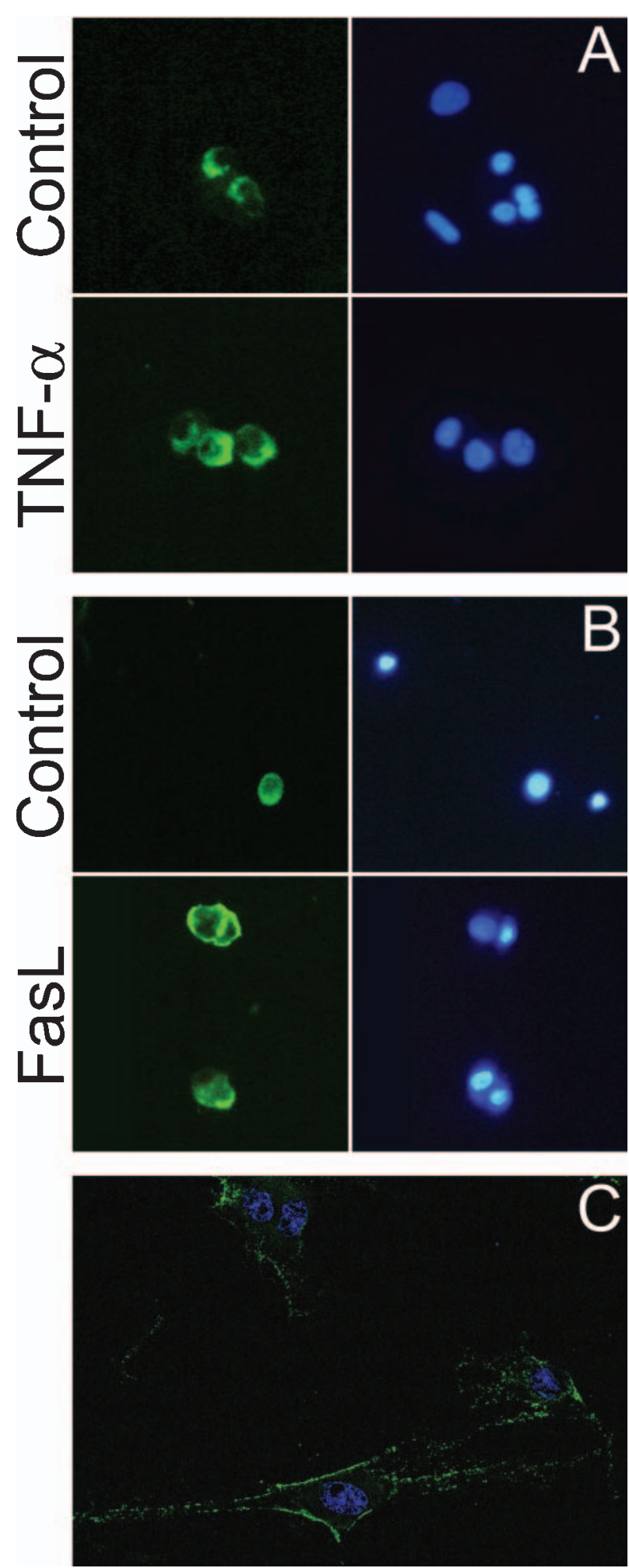

pituitary cells by infecting them with first-generation adenoviral vectors encoding TNF- $\alpha$ (RAd-hCMVTNF- $\alpha$ ), FasL (RAd-hCMV-FasL) or, as a control, $\beta-$ Gal (RAd-hCMV- $\beta-G a l)$, under the control of the human cytomegalovirus promoter (hCMV). This promoter was previously shown to successfully drive expression of $\beta-G a l$ in anterior pituitary cells and pituitary cell lines as well (Castro et al. 1997). All the encoded transgenes were efficiently transduced in infected anterior pituitary cells as detected by immunocytochemistry (Fig. 1).

In order to determine whether the overexpression of TNF- $\alpha$ or FasL induces apoptosis of anterior pituitary cells, we determined the percentage of hypodiploid cells in cultures of anterior pituitary cells from female Wistar rats after infection with increasing doses of RAd-hCMVTNF- $\alpha$, RAd-hCMV-FasL or RAd-hCMV- $\beta-G a l$. FACS cell cycle analysis showed that the infection of anterior pituitary cells with RAd-hCMV-TNF- $\alpha$ and RAd-hCMV-FasL increases the percentage of hypodiploid cells in a dose-dependent manner (Fig. 2A). In contrast, the expression of $\beta-G a l$ had no cytotoxic effects in these cultures, even at the highest dose tested (Fig. 2A). Microscopic analysis of the nuclear morphology of RAd-hCMV-TNF- $\alpha_{-}$or RAd-hCMV-FasL-infected cultures of anterior pituitary cells revealed that cells exhibited characteristic features of an apoptotic death process, such as TUNEL staining in condensed and/or fragmented nuclei (data not shown). FACS cell cycle analysis of specific subpopulations of anterior pituitary cells infected with increasing concentrations of RAdhCMV-TNF- $\alpha$, RAd-hCMV-FasL or RAd-hCMV- $\beta$ Gal showed that adenoviral-driven expression of TNF- $\alpha$ or FasL exerts a dose-dependent propapoptotic effect in lactotropes (Fig. 2B). The infection with 50 infectious units/cell (IU/cell) of RAd-hCMV-FasL induced apoptosis of somatotropes, whereas a higher dose (100 IU/cell) of RAd-hCMV-TNF- $\alpha$ was required to induce an apoptotic effect in this cell subpopulation (Fig. 2C).

The proapoptotic effect of RAd-hCMV-TNF- $\alpha$ and RAd-hCMV-FasL was also observed in anterior pituitary cells from female Sprague-Dawley rats infected with 50 IU/cell of RAd-hCMV-TNF- $\alpha$ and RAd-hCMV-FasL. TNF- $\alpha$ and FasL overexpression increased the percentage

Figure 1 Expression of TNF- $\alpha(A)$ and FasL (B and C) in primary cultures of anterior pituitary cells infected with adenoviral vectors encoding TNF- $\alpha$ (Rad-hCMV-TNF- $\alpha$ ) or FasL (Rad-hCMV-FasL) under the control of the hCMV promoter. Anterior pituitary cells from Wistar female rats were infected with 50 viral particles/cell of Rad-hCMV-TNF- $\alpha$ or Rad-hCMV-FasL for $48 \mathrm{~h}$. The expression of TNF- $\alpha$ (A) and FasL (B) was determined by indirect

immunofluorescence (right panels) and nuclei were stained with DAPI (left panels); magnification $\times 400$. (C) A confocal picture shows the expression of FasL in the cytoplasmic membrane of anterior pituitary cells infected with Rad-hCMV-FasL; magnification $\times 600$. 
of hypodiploid (Fig. 3A) and TUNEL-positive (Fig. 3B) anterior pituitary cells, whereas the expression of $\beta-G a l$ did not exert cytotoxic effects (Fig. 3A and B). Figure 3C shows that only anterior pituitary cells successfully infected with RAd-hCMV-TNF- $\alpha$ exhibit apoptotic nuclear morphology.

\section{Proapoptotic effect of TNF- $a$ and FasL transgene expression} in murine anterior pituitary cell lines

To determine whether TNF- $\alpha$ and FasL exert an apoptotic effect in tumoral anterior pituitary cells, we infected
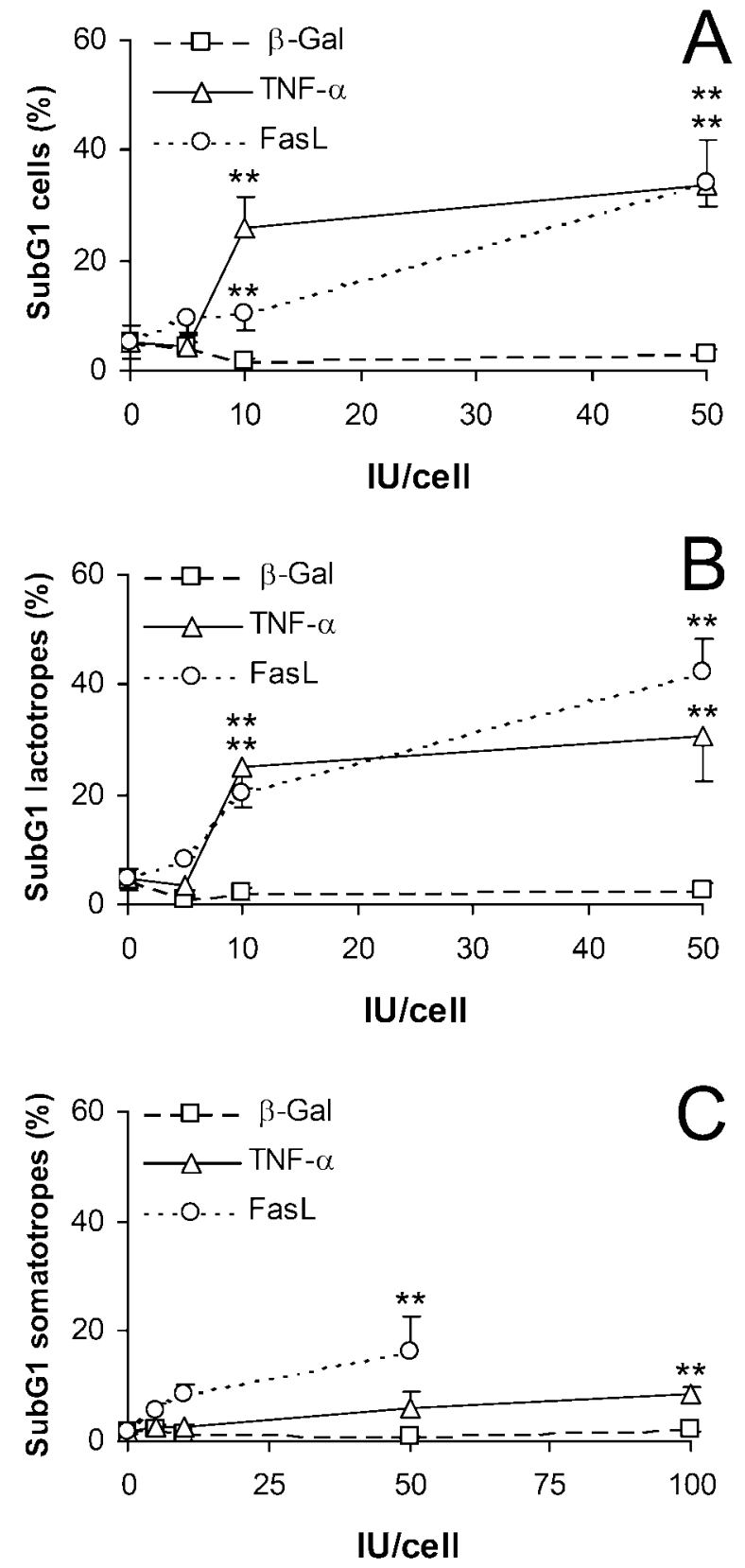

www.endocrinology-journals.org the murine anterior pituitary cell lines GH3 and AtT20 with adenoviral vectors encoding these ligands. Since the expression of death receptors has not been previously reported in the somatolactotrope cell line GH3, we first determined the presence of both TNFR 1 and Fas in these cells. We detected strong immunoreactivity for TNFR1 (Fig. 4A, left panel) and Fas (Fig. 4A, right panel) in this cell line. The expression of receptors for TNF- $\alpha$ and FasL in the murine corticotrope cell line AtT20 was previously reported (Kobayashi et al. 1997). TNF- $\alpha$ but not FasL immunoreactivity was detected in control cultures of GH3 cells. However, after infection with RAd-hCMVFasL, these cells showed a strong expression of FasL (Fig. 4B). Although we did not detect TNF- $\alpha$ or FasL immunoreactivity in control AtT20 cells, RAd-hCMVTNF- $\alpha$ and RAd-hCMV-FasL efficiently transduced these cells (Fig. 4C).

Overexpression of TNF- $\alpha$ and FasL increased the percentage of hypodiploid GH3 cells in a dose-dependent manner, whereas $\beta$-Gal expression had no cytotoxic effect even at the highest dose tested (Fig. 5A). Infection of GH3 cells with $50 \mathrm{IU} /$ cell of RAd-hCMV-TNF- $\alpha$ or RAdhCMV-FasL also increased the percentage of TUNELpositive cells (Fig. 5A). Overexpression of both vectors in AtT20 cells increased the percentage of hypodiploid cells whereas infection with RAd-hCMV- $\beta-$ Gal did not induce apoptosis (Fig. 5B). In addition, RAd-hCMVTNF- $\alpha$ or RAd-hCMV-FasL strongly enhanced the percentage of AtT20 TUNEL-positive cells (Fig. 5B).

\section{Discussion}

Previous studies have demonstrated that adenoviralencoded $\beta-G a l$ driven under the control of the hCMV promoter can be delivered to anterior pituitary cells in primary culture and into the pituitary cell lines GH3 and AtT20 (Castro et al. 1997). Our present results clearly show that adenoviral-encoded TNF- $\alpha$ and FasL induce apoptosis of both normal and tumoral anterior pituitary

Figure 2 Overexpression of TNF- $\alpha$ or FasL induces apoptosis of anterior pituitary cells from Wistar rats. Anterior pituitary cells from Wistar female rats were infected for $48 \mathrm{~h}$ with different doses of infectious units/cell (IU/cell) of adenoviral vectors encoding TNF- $\alpha$, FasL or, as a control, $\beta$-Gal, under the control of the hCMV promoter. The percentage of hypodiploid cells was determined by FACS using propidium iodide alone or combined with antibodies against prolactin or growth hormone to detect lactotropes and somatotropes respectively. (A) Each point represents the mean \pm S.E. of the percentage of sub-G1 cells from three wells/group. ${ }^{* *} P<0 \cdot 01$ vs mock-infected cells; ANOVA followed by Dunnet's test. (B) Each point represents the mean \pm S.E. of the percentage of sub-G1 lactotropes of three wells/group. ${ }^{* *} P<0 \cdot 01$ vs mock-infected cells; ANOVA followed by Dunnet's test. (C) Each point represents the mean \pm S.E. of the percentage of sub-G1 somatotropes of three wells/group. ${ }^{*} P<0 \cdot 01$ vs mock-infected cells; ANOVA followed by Dunnet's test. 

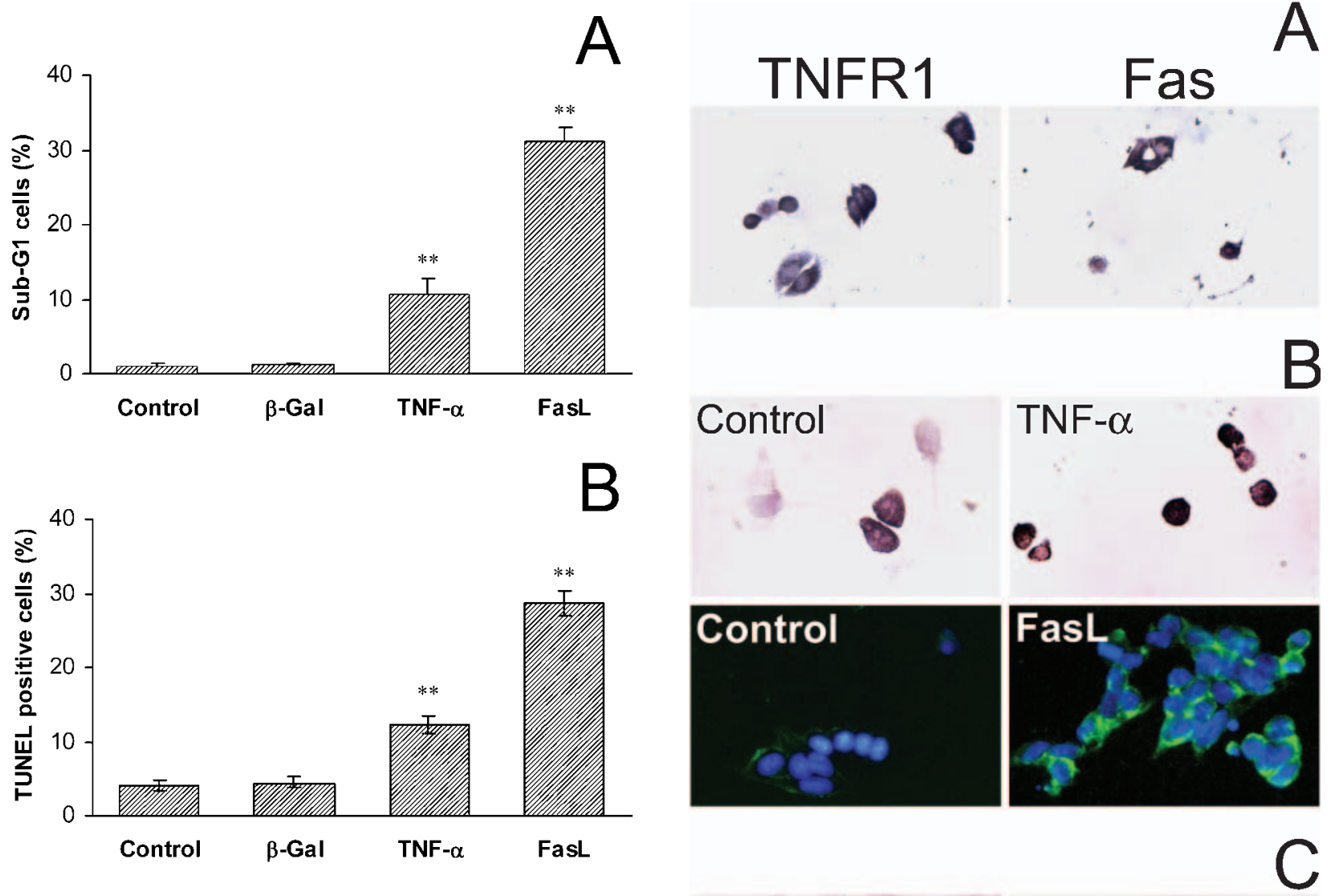

\section{TNFR1}

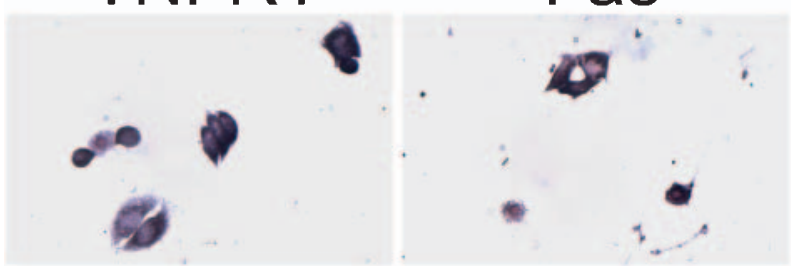

Control
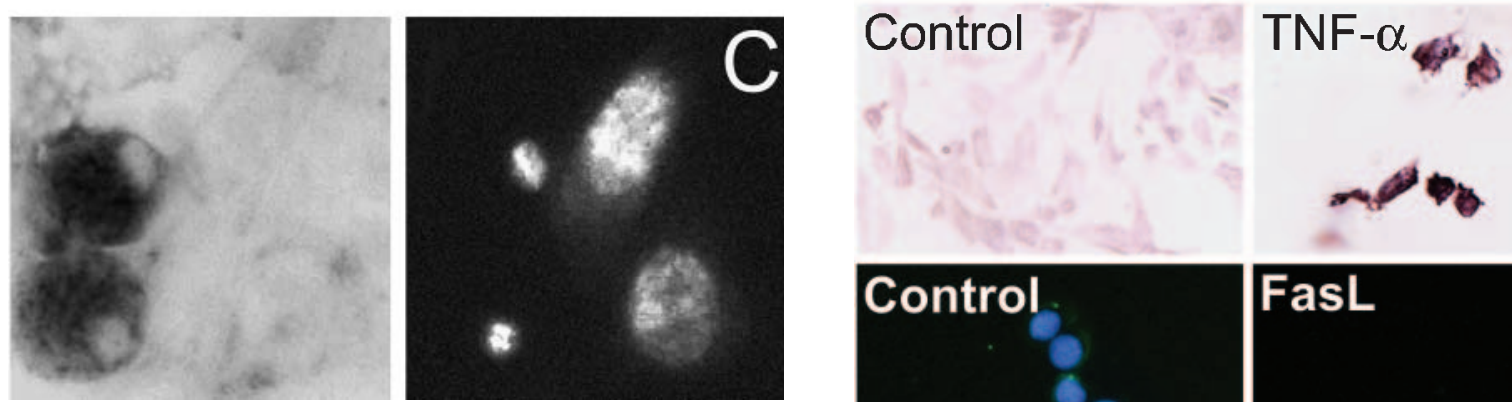

Figure 3 Overexpression of TNF- $\alpha$ or FasL induces apoptosis of anterior pituitary cells from Sprague-Dawley rats. Anterior pituitary cells from Sprague-Dawley female rats were infected for $48 \mathrm{~h}$ with $50 \mathrm{IU} /$ cell of adenoviral vectors encoding TNF- $\alpha$, FasL or, as a control, $\beta$-Gal, under the control of the hCMV promoter. (A) Nuclei were stained using propidium iodide and the percentage of hypodiploid cells was determined by FACS. Each column represents the mean \pm S.E. of the percentage of sub-G1 cells of three wells/group. ${ }^{* *} P<0 \cdot 01$ vs mock-infected cells (Control); ANOVA followed by Dunnet's test. (B) DNA fragmentation was determined by the TUNEL method. Each column represent the percentage \pm confidence limit of TUNEL-positive cells ( $n>1200$ cells/group). ${ }^{*} P<0 \cdot 01$ vs mock-infected cells (Control); $\chi^{2}$ test. (C) Expression of TNF- $\alpha$ in anterior pituitary cells infected with $50 \mathrm{IU} /$ cell of RAd-hCMV-TNF- $\alpha$. The expression of TNF- $\alpha$ was determined by immunocytochemistry (left panel) and the nuclei were stained with DAPI (right panel). Photographs show TNF- $\alpha$ immunoreactive cells exhibiting condensed apoptotic nuclei; magnification $\times 1000$.
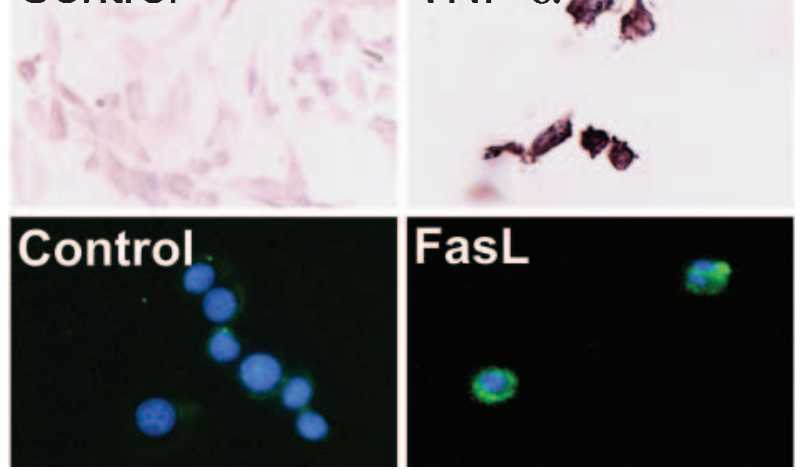

Figure 4 Expression of TNFR1 and Fas in GH3 cells (A), and of TNF- $\alpha$ and FasL in GH3 (B) and AtT20 (C) cells. (A) The expression of TNFR1 and Fas was determined by immunocytochemistry in control cultures of $\mathrm{GH} 3$ cells. (B) $\mathrm{GH} 3$ cells were infected with either $50 \mathrm{IU} /$ cell of RAd-hCMV-TNF- $\alpha$ (the expression of TNF- $\alpha$ was determined by immunocytochemistry; upper panels) or $50 \mathrm{IU} /$ cell of RAd-hCMV-FasL (the expression of Fas $L$ was determined by indirect immunofluorescence and the nuclei were stained with DAPl; lower panels). (C) AtT20 cells were infected with either $50 \mathrm{IU} /$ cell of RAd-hCMV-TNF- $\alpha$ (the expression of TNF- $\alpha$ was determined by immunocytochemistry; upper panels) or $50 \mathrm{IU} /$ cell of RAd-hCMV-FasL (the expression of FasL was determined by indirect immunofluorescence and the nuclei were stained with DAPI; lower panels). Magnification $\times 200$. 

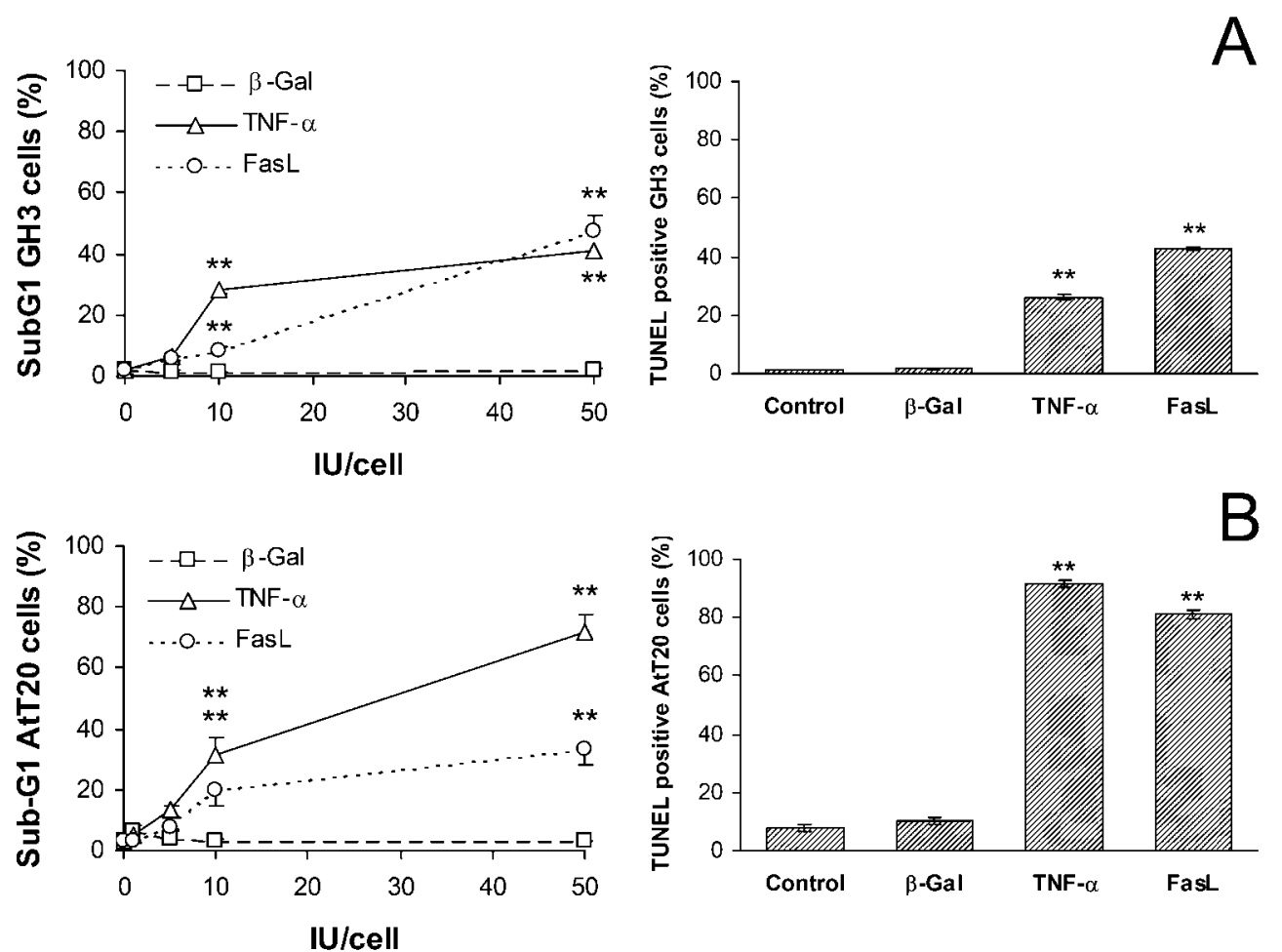

Figure 5 Overexpression of TNF- $\alpha$ and FasL induces apoptosis of somatolactotrope GH3 cells and corticototrope AtT20 cells. GH3 cells (A) and AtT20 cells (B) were infected for $48 \mathrm{~h}$ with different doses of $\mathrm{IU} /$ cell or $50 \mathrm{IU} /$ cell of adenoviral vectors encoding TNF- $\alpha$, FasL or, as a control, $\beta$-Gal, under the control of the hCMV promoter. The percentage of hypodiploid cells was determined by FACS (left panels). Each point represents the mean \pm S.E of the percentage of sub-G1 cells of three wells/group. ${ }^{* *} P<0 \cdot 01$ vs mock-infected cells; ANOVA followed by Dunnet's test. DNA fragmentation was determined by the TUNEL method (right panels). Each column represents the percentage \pm confidence limit of TUNEL-positive cells $(n>1300$ cells/group). ${ }^{* *} P<0 \cdot 01$ vs mock-infected cells (Control); $\chi^{2}$ test.

cells. Considering that the adenoviral vector encoding $\beta-G a l$ did not exert a cytotoxic effect in any of the cell types studied in our experimental conditions, the present results indicate that the proapoptotic effect of the virus encoding TNF- $\alpha$ or FasL is specifically due to the expression of these proapoptotic factors.

Previous reports indicate that anterior pituitary cells produce TNF- $\alpha$ under basal conditions (Gatti \& Bartfai 1993, Goujon et al. 1996). Although we found cells expressing TNF- $\alpha$ in control anterior pituitary cultures, hCMV promoter was effective in driving the expression of TNF- $\alpha$ within anterior pituitary cells, increasing TNF- $\alpha$ immunoreactivity. Two different types of receptors for TNF- $\alpha$ have been described: TNFR1 (55 kDa) and TNFR-2 $(75 \mathrm{kDa})$. Although both receptors are coexpressed in the majority of cells, each one can be predominant in specific cell types (Ksontini et al. 1998). Only TNFR 1 presents an intracellular death domain that triggers an apoptotic cascade (Aggarwal \& Natarajan 1996). Both TNFR1 and TNFR-2 are expressed in the mouse anterior pituitary gland (Lewis et al. 1991, Wolvers et al. 1993) but, in the pituitary of the rat only one binding site was detected for TNF- $\alpha$ (Watanobe \& Yoneda 2003), with an affinity compatible with that of TNFR1 (Lewis et al. 1991, Wolvers et al. 1993). The cell type/s of the anterior pituitary that expresses this death receptor has not been identified yet. However, our previous results have shown that TNF- $\alpha$ induces apoptosis of lactotropes and somatotropes from female rats (Candolfi et al. 2002, 2005) suggesting that at least these cell subpopulations express TNFR1. In fact, our present data show that overexpression of TNF- $\alpha$ in primary anterior pituitary cell cultures induced apoptosis of prolactin- and growth hormonebearing cells. We previously detected the expression of FasL and Fas in several anterior pituitary cell types from female rats, mainly in lactotropes and somatotropes (Jaita et al. 2005b). In addition, we reported that Fas activation induces apoptosis of lactotropes (Jaita et al. 2005b) and somatotropes as well (Jaita et al. 2005a). Our present results show that viral vectors encoding FasL exert very potent apoptotic effects in lactotropes and somatotropes. Although we cannot rule out that TNF- $\alpha$ or FasL could also induce apoptosis in other anterior pituitary subpopulations, our previous studies showed that TNF- $\alpha$ does not 
exert apoptotic effects in gonadotropes and corticotropes (Candolfi et al. 2002).

This is the first report demonstrating that the somatolactotrophic tumor GH3 cell line expresses both TNFR1 and Fas. In the corticotrophic tumor AtT20 cell line, expression of both death receptors has already been reported (Kobayashi et al. 1997, Huang et al. 2005). In GH3 and AtT20 cells, overexpression of either TNF- $\alpha$ or FasL strongly enhanced cell death by apoptosis, suggesting that death receptor-apoptotic pathways are conserved in both tumoral cell lines. Since GH3 and AtT20 cells express TNFR1 and Fas, TNF- $\alpha$ or FasL gene transfer into transformed pituitary cells may become a feasible therapeutic approach for the treatment of pituitary tumors.

Successful transgene delivery to the anterior pituitary gland has been achieved using first-generation recombinant adenoviral vectors (Castro et al. 1997, Windeatt et al. 2000, Lee et al. 2001a,b, Southgate et al. 2001, Williams et al. 2001). Although the safety of intrapituitary administration of adenoviral vectors remains controversial (Davis et al. 2001, Southgate et al. 2001, Carri et al. 2005), several transgenes have been shown to be promising gene therapy targets for pituitary adenomas: such as HSV Type 1 thymidine kinase (HSV1-TK) (Lee et al. 1999, Windeatt et al. 2000), tyrosine hydroxylase (Williams et al. 2001) and the diphtheria toxin gene (Lee \& Jameson 2002) - all of which have been shown to reduce pituitary growth and hyperprolactinemia in murine pituitary tumor models (Lee \& Jameson 2005). Considering that the TNFR1/ TNF- $\alpha$ and Fas/FasL systems can act in an auto/paracrine manner, one advantage of TNF- $\alpha$ or FasL gene transfer is that if not all the tumor cells are successfully transduced, the transduced cells, even if few in number, could induce apoptosis in the neighboring cells. Although this could result in toxic effects on normal surrounding tissue, the low diffusibility of replication-defective adenoviral vectors throughout the pituitary gland (Davis et al. 2001, Southgate et al. 2001, Carri et al. 2005) ensures the expression of the transgene only inside the tumor mass. We previously described the low toxicity of RAd-hCMV-FasL in the brain (Ambar et al. 1999), which was neither associated with local morphologic changes (such as apoptosis of brain parenchyma cells) nor with systemic alterations; suggesting that the overexpression of death receptor ligands in the pituitary would constitute a safe approach for the treatment of pituitary adenomas. Nevertheless, adenoviral vectors can be engineered to have even lower toxicity. The incorporation of pituitary hormone promoters (Castro et al. 1997, Lee et al. 2000, 2001b, Davis et al. 2001, Southgate et al. 2001) into viral vectors has shown to drive transgene expression selectively in specific endocrine pituitary cell populations in vivo (Southgate et al. 2001, Roche et al. 2004). On the other hand, inducible promoter systems driving transgene expression have allowed for tight regulation of transgene expression in the pituitary gland (Smith-Arica et al. 2001, Williams et al. 2001).

In conclusion, considering that apoptosis plays a central role in regulation of pituitary tissue homeostasis, the imbalance between cell death and proliferation in favor of cell survival could result in tumor formation. One of the commonly employed strategies in experimental gene therapy for cancer is to target death receptors specifically to trigger apoptosis in tumor cells (Bianco et al. 2003, Nakanishi et al. 2003, Rubinchik et al. 2003, Sanlioglu et al. 2004). Our results indicate that forced overexpression of TNF- $\alpha$ or FasL induces apoptosis of normal and tumoral pituitary cells and suggest that TNF- $\alpha$ and FasL gene transfer may be suitable to promote apoptosis of TNFR1 or Fas positive pituitary tumoral cells.

\section{Funding}

This project was supported by grants from Agencia Nacional de Investigaciones Científicas y Tecnológicas, CONICET and Universidad de Buenos Aires, Argentina and by a 1RO3 grant (TW006273-01) from the FIRCA program of the National Institutes of Health, USA to M G C and A S. National Institutes of Health/National Institute of Neurological Disorders and Stroke grants (NS 42893.01, U54 NS045309-01, and 1R21 NS047298-01) and The Linda Tallen \& David Paul Kane Annual Fellowship were received by M GC. The authors declare that there is no conflict of interest that would prejudice the impartiality of this scientific work.

\section{References}

Aggarwal BB \& Natarajan K 1996 Tumor necrosis factors: developments during the last decade. European Cytokine Network 7 93-124

Alexander JM, Biller BM, Bikkal H, Zervas NT, Arnold A \& Klibanski A 1990 Clinically nonfunctioning pituitary tumors are monoclonal in origin. Journal of Clinical Investigation 86 336-340.

Ambar BB, Frei K, Malipiero U, Morelli AE, Castro MG, Lowenstein PR \& Fontana A 1999 Treatment of experimental glioma by administration of adenoviral vectors expressing Fas ligand. Human Gene Therapy 10 1641-1648.

Asa SL \& Ezzat S 2002 The pathogenesis of pituitary tumours. Nature Reviews in Cancer 2 836-849.

Ashkenazi A \& Dixit VM 1998 Death receptors: signaling and modulation. Science 281 1305-1308.

Bianco SR, Sun J, Fosmire SP, Hance K, Padilla ML, Ritt MG, Getzy DM, Duke RC, Withrow SJ, Lana S et al. 2003 Enhancing antimelanoma immune responses through apoptosis. Cancer Gene Therapy $10726-736$.

Candolfi M, Zaldivar V, De Laurentiis A, Jaita G, Pisera D \& Seilicovich A 2002 TNF-alpha induces apoptosis of lactotropes from female rats. Endocrinology 143 3611-3617.

Candolfi M, Jaita G, Zaldivar V, Zarate S, Pisera D \& Seilicovich A 2004 Tumor necrosis factor-alpha-induced nitric oxide restrains the apoptotic response of anterior pituitary cells. Neuroendocrinology 80 83-91. 
Candolfi M, Jaita G, Zaldivar V, Zarate S, Ferrari L, Pisera D, Castro MG \& Seilicovich A 2005 Progesterone antagonizes the permissive action of estradiol on tumor necrosis factor-alpha-induced apoptosis of anterior pituitary cells. Endocrinology 146 736-743.

Carri NG, Sosa YE, Brown OA, Albarino C, Romanowski V \& Goya RG 2005 Studies on in vivo gene transfer in pituitary tumors using herpes-derived and adenoviral vectors. Brain Research Bulletin 65 17-22.

Castro MG, Goya RG, Sosa YE, Rowe J, Larregina A, Morelli A \& Lowenstein PR 1997 Expression of transgenes in normal and neoplastic anterior pituitary cells using recombinant adenoviruses: long term expression, cell cycle dependency, and effects on hormone secretion. Endocrinology 138 2184-2194.

Cecconi F 1999 Apaf1 and the apoptotic machinery. Cell Death Differentiation 6 1087-1098.

Chen G \& Goeddel DV 2002 TNF-R1 signaling: a beautiful pathway. Science 296 1634-1635.

Davis JR, McVerry J, Lincoln GA, Windeatt S, Lowenstein PR, Castro MG \& McNeilly AS 2001 Cell type-specific adenoviral transgene expression in the intact ovine pituitary gland after stereotaxic delivery: an in vivo system for long-term multiple parameter evaluation of human pituitary gene therapy. Endocrinology 142 795-801.

Degterev A, Boyce M \& Yuan J 2003 A decade of caspases. Oncogene 22 8543-8567.

Ehtesham M, Samoto K, Kabos P, Acosta FL, Gutierrez MA, Black KL \& Yu JS 2002 Treatment of intracranial glioma with in situ interferon-gamma and tumor necrosis factor-alpha gene transfer. Cancer Gene Therapy 9 925-934.

Eischen CM, Packham G, Nip J, Fee BE, Hiebert SW, Zambetti GP \& Cleveland JL 2001 Bcl-2 is an apoptotic target suppressed by both c-Myc and E2F-1. Oncogene 20 6983-6993.

Evan G \& Littlewood T 1998 A matter of life and cell death. Science 281 1317-1322.

Gatti S \& Bartfai T 1993 Induction of tumor necrosis factor-alpha mRNA in the brain after peripheral endotoxin treatment: comparison with interleukin-1 family and interleukin-6. Brain Research 624 291-294.

Gonzalvez F, Pariselli F, Dupaigne P, Budihardjo I, Lutter M, Antonsson B, Diolez P, Manon S, Martinou JC, Goubern M et al. 2005 tBid interaction with cardiolipin primarily orchestrates mitochondrial dysfunctions and subsequently activates Bax and Bak. Cell Death Differentiation 12 614-626.

Goujon E, Parnet P, Laye S, Combe C \& Dantzer R 1996 Adrenalectomy enhances pro-inflammatory cytokines gene expression, in the spleen, pituitary and brain of mice in response to lipopolysaccharide. Brain Research Molecular Brain Research 36 53-62.

Hashi A, Mazawa S, Kato J \& Arita J 1995 Pentobarbital anesthesia during the proestrous afternoon blocks lactotroph proliferation occurring on estrus in female rats. Endocrinology 136 4665-4671.

Herman V, Fagin J, Gonsky R, Kovacs K \& Melmed S 1990 Clonal origin of pituitary adenomas. Journal of Clinical Endocrinology and Metabolism 71 1427-1433.

Huang P, Tofighi R, Emgard M \& Ceccatelli S 2005 Cell death induced by $2,3,7,8$-tetrachlorodibenzo-p-dioxin $(2,3,7,8$-TCDD) in AtT-20 pituitary cells. Toxicology 207 391-399.

Jaita G, Candolfi M, Zaldivar V, Ferrari L, Pisera D, Castro M \& Seilicovich A $2005 a$ Influence of $17 \beta$-estradiol on the Fas/FasL system in the anterior pituitary. In 87th Annual Meeting of the Endocrine Society, San Diego, CA, USA, p 667.

Jaita G, Candolfi M, Zaldivar V, Zarate S, Ferrari L, Pisera D, Castro MG \& Seilicovich A $2005 b$ Estrogens up-regulate the Fas/FasL apoptotic pathway in lactotropes. Endocrinology 146 4737-4744.

Kobayashi H, Fukata J, Murakami N, Usui T, Ebisui O, Muro S, Hanaoka I, Inoue K, Imura H \& Nakao K 1997 Tumor necrosis factor receptors in the pituitary cells. Brain Research 758 45-50.
Ksontini R, MacKay SL \& Moldawer LL 1998 Revisiting the role of tumor necrosis factor alpha and the response to surgical injury and inflammation. Archives in Surgery 133 558-567.

Larregina AT, Morelli AE, Dewey RA, Castro MG, Fontana A \& Lowenstein PR 1998 FasL induces Fas/Apo1-mediated apoptosis in human embryonic kidney 293 cells routinely used to generate E1-deleted adenoviral vectors. Gene Therapy 5 563-568.

Lee EJ \& Jameson JL 2002 Cell-specific Cre-mediated activation of the diphtheria toxin gene in pituitary tumor cells: potential for cytotoxic gene therapy. Human Gene Therapy 13 533-542.

Lee EJ \& Jameson JL 2005 Gene therapy of pituitary diseases. Journal of Endocrinology 185 353-362.

Lee EJ, Anderson LM, Thimmapaya B \& Jameson JL 1999 Targeted expression of toxic genes directed by pituitary hormone promoters: a potential strategy for adenovirus-mediated gene therapy of pituitary tumors. Journal of Clinical Endocrinology and Metabolism 84 786-794.

Lee EJ, Thimmapaya B \& Jameson JL 2000 Stereotactic injection of adenoviral vectors that target gene expression to specific pituitary cell types: implications for gene therapy. Neurosurgery 46 1461-1468, discussion 1468-1469.

Lee EJ, Duan WR, Jakacka M, Gehm BD \& Jameson JL 2001a Dominant negative ER induces apoptosis in $\mathrm{GH}(4)$ pituitary lactotrope cells and inhibits tumor growth in nude mice. Endocrinology 142 3756-3763.

Lee EJ, Martinson F, Kotlar T, Thimmapaya B \& Jameson JL $2001 b$ Adenovirus-mediated targeted expression of toxic genes to adrenocorticotropin-producing pituitary tumors using the proopiomelanocortin promoter. Journal of Clinical Endocrinology and Metabolism 86 3400-3409.

Lewis M, Tartaglia LA, Lee A, Bennett GL, Rice GC, Wong GH, Chen EY \& Goeddel DV 1991 Cloning and expression of cDNAs for two distinct murine tumor necrosis factor receptors demonstrate one receptor is species specific. PNAS 88 2830-2834.

Lowenstein PR SA, Bain D, Castro MG \& Wilkinson GWG 1996 The use of adenovirus vectors to transfer genes to identified target brain cells 'in vitro.' In Protocols for Gene Transfer in Neuroscience Towards Gene Therapy of Neurological Disorders, pp 81-92. Ed PR Lowenstein. New York, NY, USA: John Wiley.

Maleniak TC, Darling JL, Lowenstein PR \& Castro MG 2001 Adenovirus-mediated expression of HSV1-TK or Fas ligand induces cell death in primary human glioma-derived cell cultures that are resistant to the chemotherapeutic agent CCNU. Cancer Gene Therapy 8 589-598.

Melmed S 2003 Mechanisms for pituitary tumorigenesis: the plastic pituitary. Journal of Clinical Investigation 112 1603-1618.

Morelli AE, Larregina AT, Smith-Arica J, Dewey RA, Southgate TD, Ambar B, Fontana A, Castro MG \& Lowenstein PR 1999 Neuronal and glial cell type-specific promoters within adenovirus recombinants restrict the expression of the apoptosis-inducing molecule Fas ligand to predetermined brain cell types, and abolish peripheral liver toxicity. Journal of Gene Virology 80 571-583.

Nakanishi H, Mazda O, Satoh E, Asada H, Morioka H, Kishida T, Nakao M, Mizutani Y, Kawauchi A, Kita M et al. 2003 Nonviral genetic transfer of Fas ligand induced significant growth suppression and apoptotic tumor cell death in prostate cancer in vivo. Gene Therapy 10 434-442.

Norbury CJ \& Zhivotovsky B 2004 DNA damage-induced apoptosis. Oncogene 23 2797-2808.

Roche C, Zamora AJ, Taieb D, Lavaque E, Rasolonjanahary R, Dufour H, Bagnis C, Enjalbert A \& Barlier A 2004 Lentiviral vectors efficiently transduce human gonadotroph and somatotroph adenomas in vitro. Targeted expression of transgene by pituitary hormone promoters. Journal of Endocrinology 183 217-233.

Rubinchik S, Yu H, Woraratanadharm J, Voelkel-Johnson C, Norris JS \& Dong JY 2003 Enhanced apoptosis of glioma cell lines is achieved by co-delivering FasL-GFP and TRAIL with a complex Ad5 vector. Cancer Gene Therapy 10 814-822. 
Sanlioglu AD, Aydin C, Bozcuk H, Terzioglu E \& Sanlioglu S 2004 Fundamental principals of tumor necrosis factor-alpha gene therapy approach and implications for patients with lung carcinoma. Lung Cancer 44 199-211.

Scaffidi C, Schmitz I, Zha J, Korsmeyer SJ, Krammer PH \& Peter ME 1999 Differential modulation of apoptosis sensitivity in CD95 type I and type II cells. Journal of Biological Chemistry $27422532-22538$.

Smith-Arica JR, Williams JC, Stone D, Smith J, Lowenstein PR \& Castro MG 2001 Switching on and off transgene expression within lactotrophic cells in the anterior pituitary gland in vivo. Endocrinology 142 2521-2532.

Southgate T, Kingston P \& Castro MG 2000a Gene transer into neural cells in vivo using adenoviral vectors. In Current Protocols in

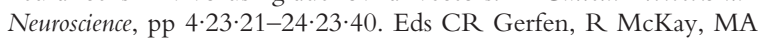
Rogawski, DR Sibley \& P Skolnick. New York, NY, USA: John Wiley.

Southgate T, Windeatt S, Smith-Arica J, Gerdes C, Perone MJ, Morris I, Davis J, Klatzmann D, Lowenstein PR \& Castro MG $2000 \mathrm{~b}$ Transcriptional targeting to anterior pituitary lactotrophic cells using recombinant adenovirus vectors in vitro and in vivo in normal and estrogen/supliride-induced hyperplastic anterior pituitaries. Endocrinology 141 3493-3505.

Southgate TD, Stone D, Williams JC, Lowenstein PR \& Castro MG 2001 Long-term transgene expression within the anterior pituitary gland in situ: impact on circulating hormone levels, cellular and antibody-mediated immune responses. Endocrinology 142 464-476.
Watanobe H \& Yoneda M 2003 A mechanism underlying the sexually dimorphic ACTH response to lipopolysaccharide in rats: sex steroid modulation of cytokine binding sites in the hypothalamus. Journal of Physiology $\mathbf{5 4 7} 221-232$.

Williams JC, Stone D, Smith-Arica JR, Morris ID, Lowenstein PR \& Castro MG 2001 Regulated, adenovirus-mediated delivery of tyrosine hydroxylase suppresses growth of estrogen-induced pituitary prolactinomas. Molecular Therapy 4 593-602.

Windeatt S, Southgate TD, Dewey RA, Bolognani F, Perone MJ, Larregina AT, Maleniak TC, Morris ID, Goya RG, Klatzmann D et al. 2000 Adenovirus-mediated herpes simplex virus type-1 thymidine kinase gene therapy suppresses oestrogen-induced pituitary prolactinomas. Journal of Clinical Endocrinology and Metabolism 85 1296-1305.

Wolvers DA, Marquette C, Berkenbosch F \& Haour F 1993 Tumor necrosis factor-alpha: specific binding sites in rodent brain and pituitary gland. European Cytokine Network 4 377-381.

Yin P \& Arita J 2002 Proestrous surge of gonadotropin-releasing hormone secretion inhibits apoptosis of anterior pituitary cells in cycling female rats. Neuroendocrinology 76 272-282.

Received in final form 10 February 2006

Accepted 8 March 2006

Made available online as an Accepted Preprint

24 March 2006 